\title{
Trap-nesting bees (Hymenoptera, Apoidea) in areas of dry semideciduous forest and caatinga, Bahia, Brazil
}

\author{
Cândida M. L. Aguiar ${ }^{1}$, Carlos A. Garófalo ${ }^{2} \&$ Gesline F. Almeida ${ }^{2}$ \\ ${ }^{1}$ Departamento de Ciências Biológicas, Universidade Estadual de Feira de Santana. Rodovia BR 116, km 3, 44031-460 Feira \\ de Santana, Bahia, Brasil. E-mail: claguiar@uefs.br \\ ${ }^{2}$ Departamento de Biologia, Faculdade de Filosofia, Ciências e Letras de Ribeirão Preto, Universidade de São Paulo. 14040- \\ 901 Ribeirão Preto, São Paulo, Brasil. E-mail: garofalo@ffclrp.usp.br, gesline@ usp.br
}

\begin{abstract}
In this study were examined the species richness and seasonal abundance of cavity-nesting bees in areas of dry semi-deciduous forest and caatinga in the State of Bahia, Brazil. Sampling was done employing two types of trap-nests: bamboo canes and tubes made of black cardboard with dimensions of either $58 \times 6 \mathrm{~mm}$ or 105 $x 8 \mathrm{~mm}$. The traps were inspected once a month. One hundred and forty-six nests of 11 bee species were collected in the forest, and 121 nests of seven species were collected in the caatinga. Five species of cleptoparasitic bees were also reared from these nests. The highest nesting frequencies occurred in the wet season in both areas. Nests parasitism was important only for Centris tarsata Smith, 1874, and was higher at the caatinga site than in the forest. The mortality of pre-emergent adults was high, especially in C. tarsata, Tetrapedia diversipes Klug, 1810 and Euglossa cordata (Linnaeus, 1758). Information on the number of cells per nest, the size, shape, and arrangement of brood cells in the nests, as well as the number of adults produced and the number of generations per year are also presented. Species richness, temporal patterns of nesting, and percentage of parasitism were compared with other habitats. KEY WORDS. Nesting biology, solitary bees, South American dry forests, trap-nests.
\end{abstract}

RESUMO. Abelhas (Hymenoptera, Apoidea) que nidificam em ninhos-armadilha em áreas de floresta semidecídua e caatinga, Bahia, Brasil. Neste estudo foram investigadas a riqueza de espécies e a abundância sazonal de abelhas que nidificam em cavidades em áreas de Floresta estacional semi-decídua e Caatinga na Bahia. A amostragem foi realizada com dois tipos de ninhos-armadilha (= N.A.): gomos de bambu e tubos de cartolina preta ( 58 × 6 mm e $105 \times 8$ mm). Os N.A. foram inspecionados uma vez por mês. Foram coletados 146 ninhos de 11 espécies de abelhas na floresta e 121 ninhos de sete espécies na caatinga. Além disso, cinco espécies de abelhas cleptoparasitas foram criadas a partir destes ninhos. As frequiências de nidificação mais altas ocorreram na estação úmida em ambas as áreas. Parasitismo de ninhos foi importante apenas para Centris tarsata Smith, 1874, e foi mais alto na caatinga do que na área de floresta. A mortalidade de adultos pré-emergentes foi alta, especialmente em C. tarsata, Tetrapedia diversipes Klug, 1810 e Euglossa cordata (Linnaeus, 1758). Informações sobre o número de células por ninho, tamanho, forma e arranjo das células nos ninhos, assim como o número de adultos produzidos e o número de gerações por ano foram também apresentados. A riqueza de espécies, os padrões temporais de nidificação e o percentual de parasitismo foram comparados com outros habitats.

PALAVRAS CHAVE. Abelhas solitárias, biologia de nidificação, florestas secas sul-americanas, ninhos-armadilha.

The use of trap-nests in studies with solitary bee species that nest in preexisting cavities has provide a considerable increase on the knowledge of biology of those species. Some of the studies were made to obtain information on the nesting biology (Krombein 1967, Strickler et al. 1996, Pereira et al. 1999, Morato et al. 1999, Jesus \& Garófalo 2000, Silva et al. 2001, Aguiar \& GARófAlo 2004, ZiLLiKENS \& STEINER 2004), whereas other provide information on population dynamics (Jayasingh \& Freeman 1980), preferred habitats (Frankie et al. 1988, GATHMANN et al. 1994), reproductive biology of parasites which hosts nest in trap-nests (ScotT et al. 2000, Gazola \& Garófalo 2003) and composition and seasonal patterns of communities (CAMILLo et al. 1995, Garófalo 2000, Viana et al. 2001, Aguiar \& Martins, 2002; Alves-dos-SAntos 2003). More recently, trap-nesting bees and wasps have been used in researches designed to evaluate the habitat quality (FrankIE et al. 1998, TsCHARNTKE et al. 1998), the effects of habitat fragmentation and of the landscape complexity on community composition and predator-prey interactions (Morato \& Campos 2000, Morato 2001, Steffan-Dewenter 2002, KRUESS \& TSCHARNTKE 2002). 
In this study we examine the richness and abundance of bee species that nest in preexiting cavities in relation to two different habitat types: caatinga (dry savana) and dry semi-deciduous forest. Furthermore, we provide information on several bionomical aspects of the species that occupied the traps.

\section{MATERIAL AND METHODS}

The study was conducted in an area of caatinga of Sempre Verde Farm, Ipirá (12 $13^{\prime} 09^{\prime \prime}$ S, 3949'53”W), Bahia, and in a dry semi-deciduous forest of Olhos d'Água Farm, Baixa Grande $\left(12^{\circ} 00^{\prime} 29^{\prime \prime} \mathrm{S}, 40^{\circ} 17^{\prime} 21^{\prime \prime} \mathrm{W}\right)$, Bahia. The climate in Ipirá is semiarid, with an average annual temperature of $23.7^{\circ} \mathrm{C}$ (average maximum of $28.9^{\circ} \mathrm{C}$ and average minimum of $19.9^{\circ} \mathrm{C}$ ) and an average annual rainfall of $754 \mathrm{~mm}$ (range 157-1560 mm/year) (BAHIA 1994). During this study, the dry season extended from February/March to September/October. The rainy season started in October/November and continued until January/February, although it was interrupted by intermittent dry periods. The vegetation in the area is an open arboreal caatinga, often converted to pasture. In Baixa Grande, the climate ranges from dry to sub-humid. The average annual temperature is $23.6^{\circ} \mathrm{C}$ (average maximum of $29^{\circ} \mathrm{C}$ and average minimum of $19.7^{\circ} \mathrm{C}$ ) and the average annual rainfall is $820 \mathrm{~mm}$ (range $368-1204 \mathrm{~mm} /$ year) (BAHIA 1994). During the study period, the rainy season began in October and extended until March/April, while the dry season started in April/May and ended in August/ September. The trap-nests were placed in a forest fragment surrounded by bean crop fields.

As described by CAmillo et al. (1995), the trap-nests used consisted of hollow bamboo canes, which were cut so that a nodal septum closed one end of the cane, and tubes of black cardboard, with one end closed with the same material. The bamboo canes varied in internal diameter from 5.0 to $25.0 \mathrm{~mm}$ and had variable lengths. The tubes were of two sizes (length $\mathrm{x}$ internal diameter): $10.5 \times 0.8 \mathrm{~cm}$ ( = large tubes) and $5.8 \times 0.6 \mathrm{~cm}$ ( = small tubes). These tubes were inserted into horizontal holes drilled into wooden plates ( 54 holes per plate). The canes and the wooden plates were placed along steel shelves covered with a plastic tarpaulin in order to protect them from the sun and the rain. Two sampling sites were established in each area: one in a forest fragment (BG-I) and the other in a farm shed (BG-II), $600 \mathrm{~m}$ far from BG-I, in Baixa Grande; and one in a pasture (IP-III) and the other far $700 \mathrm{~m}$, in an area of caatinga (IP-IV) in Ipirá. A total of 270 cardboard tubes of both sizes plus 100 bamboo canes were set up at each sampling site, except for site BG-II where 108 small tubes, 54 large tubes, and 50 bamboo canes were set up.

The trap-nests were inspected once a month from September 1999 to February 2001 in Ipirá, and from November 1998 to February 2001 in Baixa Grande. Each inspection was made with the aid of an otoscope. When traps contained complete nests, they were collected and replaced with empty ones. The traps occupied by females were marked and left at their original places. If completed, such nests were removed to the laboratory in the next inspection. In the laboratory, each trapnest was introduced into a transparent glass or plastic tube, 4.0-5.0 $\mathrm{cm}$ longer than the trap, with one end closed with a cork. As adult emerged into the glass/plastic tube, the trap was removed and the individuals were collected. The nests were kept at room temperature and observed daily until the adults emerged. A few days after the last emergence from any given nest occurred, the nest was opened and its contents analyzed. Cells and nests from which nothing emerged were also opened, and the cause and stage of mortality were recorded. Voucher specimens of bees are deposited in the CUFS collection, Universidade Estadual de Feira de Santana, Bahia.

Statistical tests follow ZAR (1984) and were performed by using the statistical package SigmaStat for Windows (1994Jandel Corporation, San Rafael, CA). Chi-square tests were used to compare number of nests by area, immature mortality, and sex ratio. Pearson correlation analysis was performed to verify the intensity of association between frequency of nesting in each area and monthly rainfall. Throughout the text all means (x) are given $\pm \mathrm{SD}$.

\section{RESULTS}

\section{Bee species richness and abundance}

The number of species that occupied the traps in Baixa Grande was higher than that observed in Ipira (Tab. I). In addition to the listed species in table I, other five unidentified species used the traps: one species of Centris Fabricius, 1804 (one nest, at site BG-I) and one species of Megachile Latreille, 1802 (two nests at site BG-I and one nest at site BG-II) nested in Baixa Grande, one species of Anthodioctes Holmberg, 1903 (one nest at site IP-IV) and one species of Megachile (Dactylomegachile) (five nests at site IP-III) nested in Ipirá, and one species of Ephantidium Moure, 1947 nested in both areas (two nests at BG-I, one nest at IP-III and four nests at IP-IV).

In Baixa Grande, of the 146 nests built by 11 bee species, 104 were collected at site BG-I and 42 at site BG-II. There was no difference between the frequencies of occupation of traps in relation to the number of exposed trap in each site $\left(\chi^{2}=\right.$ $1.18 ; \mathrm{df}=1 ; \mathrm{p}=0.277$ ). Of the 121 nests obtained from Ipira, 52 were established at site IP-III and 69 at site IP-IV. These nests were built by females of seven bee species. Similar to found in Baixa Grande, there was no difference between the number of nests established in each site $\left(\chi^{2}=2.34 ; \mathrm{df}=1 ; \mathrm{p}=0.126\right)$. Only four species nested in both areas and Centris tarsata Smith, 1874 was the most abundant species in Baixa Grande (37\% of total nests) and also in Ipira (55\% of total nests) (Tab. I). The natural enemies associated with the nests were Mesocheira bicolor (Fabricius, 1804), Coelioxoides waltheriae Ducke, 1908, and one unidentified species of Coelioxys Latreille, 1809 in Baixa Grande, and M. bicolor and two unidentified species of Coelioxys in Ipira.

In general, in both areas nesting occurred mainly from November to March (Tabs II and III), which corresponds to the

Revista Brasileira de Zoologia 22 (4): 1030-1038, dezembro 2005 
Table I. Trap-nesting bees and number of nests obtained in each sampling site in Baixa Grande (BG-I and BG-II), from November 1998 to February 2001, and Ipira (IP-III and IP-IV), from September 1999 to February 2001.

\begin{tabular}{|c|c|c|c|c|}
\hline \multirow{2}{*}{ Species } & \multicolumn{4}{|c|}{ Number of nests per site } \\
\hline & BG-I & BG-II & IP-III & IP-IV \\
\hline \multicolumn{5}{|l|}{ Apidae } \\
\hline Centris tarsata Smith, 1874 & 35 & 18 & 27 & 39 \\
\hline Centris analis (Fabricius, 1804) & 3 & 6 & - & - \\
\hline Euglossa cordata (Linnaeus, 1758) & 7 & 3 & 11 & 16 \\
\hline Tetrapedia diversipes Klug,1810 & 24 & 3 & - & - \\
\hline Xylocopa grisescens Lepeletier, 1841 & - & 1 & - & - \\
\hline Xylocopa frontalis (Oliver, 1789) & 24 & - & 1 & 5 \\
\hline \multicolumn{5}{|l|}{ Megachilidae } \\
\hline Dicranthidium arenarium (Ducke, 1907) & 5 & 9 & - & - \\
\hline Dicranthidium luciae Urban, 1992 & 1 & 1 & - & - \\
\hline Megachile lissotate Moure, 1943 & - & - & 7 & 4 \\
\hline
\end{tabular}

Table II. Number of nests obtained monthly, from November 1998 to February 2001, in Baixa Grande, Bahia.

\begin{tabular}{|c|c|c|c|c|c|c|c|c|c|c|c|c|}
\hline \multirow{3}{*}{ Species } & \multicolumn{12}{|c|}{ Number of nests/month/year } \\
\hline & J & $\mathrm{F}$ & M & A & M & J & J & A & $S$ & $\mathrm{O}$ & $\mathrm{N}$ & $\mathrm{D}$ \\
\hline & $99 / 00 / 01$ & $99 / 00 / 01$ & $99 / 00$ & $99 / 00$ & $99 / 00$ & $99 / 00$ & $99 / 00$ & $99 / 00$ & $99 / 00$ & $99 / 00$ & $98 / 99 / 00$ & $98 / 99 / 00$ \\
\hline Centris tarsata & $0 / 0 / 2$ & $5 / 2 / 0$ & $5 / 2$ & $3 / 1$ & $2 / 0$ & & & & $1 / 3$ & $4 / 0$ & $1 / 10 / 1$ & $5 / 5 / 1$ \\
\hline Centris analis & & & & & & $0 / 1$ & $0 / 4$ & $0 / 3$ & & & $0 / 1 / 0$ & \\
\hline Euglossa cordata & $0 / 0 / 1$ & & $0 / 1$ & & & $0 / 2$ & & $0 / 1$ & & & $0 / 3 / 1$ & $0 / 1 / 0$ \\
\hline Tetrapedia diversipes & $0 / 4 / 1$ & $0 / 10 / 0$ & $0 / 6$ & $0 / 4$ & & & & & & & $0 / 1 / 0$ & $0 / 1 / 0$ \\
\hline Xylocopa grisescens & & & & & & & & & & & $0 / 0 / 1$ & \\
\hline Xylocopa frontalis & & $0 / 4 / 0$ & $0 / 4$ & $0 / 2$ & $0 / 2$ & & $0 / 3$ & & $0 / 1$ & $0 / 1$ & $0 / 0 / 6$ & $0 / 0 / 1$ \\
\hline Dicranthidium arenarium & $0 / 5 / 1$ & $0 / 4 / 0$ & $0 / 3$ & & & & & & & & & $0 / 1 / 0$ \\
\hline Dicranthidium luciae & & & $0 / 1$ & & & & & & & & & $0 / 1 / 0$ \\
\hline
\end{tabular}

Table III. Number of nests obtained monthly, from September 1999 to February 2001, in Ipirá, Bahia.

\begin{tabular}{|c|c|c|c|c|c|c|c|c|c|c|c|c|}
\hline \multirow{3}{*}{ Species } & \multicolumn{12}{|c|}{ Number of nests/month/year } \\
\hline & J & $\mathrm{F}$ & $\mathrm{M}$ & $\mathrm{A}$ & $\mathrm{M}$ & J & $\mathrm{J}$ & A & $S$ & $\mathrm{O}$ & $\mathrm{N}$ & $\mathrm{D}$ \\
\hline & $00 / 01$ & $00 / 01$ & 00 & 00 & 00 & 00 & 00 & 00 & $99 / 00$ & $99 / 00$ & $99 / 00$ & $99 / 00$ \\
\hline Centris tarsata & $5 / 4$ & $10 / 4$ & 4 & & & & & & $0 / 2$ & $0 / 1$ & $10 / 5$ & $11 / 10$ \\
\hline Euglossa cordata & $0 / 4$ & $5 / 5$ & 7 & & 3 & & & & $3 / 0$ & & & \\
\hline Xylocopa frontalis & $0 / 1$ & $0 / 1$ & & 1 & & & & & 1 & & $0 / 1$ & $0 / 1$ \\
\hline Megachile lissotate & & $3 / 1$ & & & & 1 & 2 & & & & & $4 / 0$ \\
\hline
\end{tabular}

period of greatest rainfall. In Baixa Grande, however, no significant correlation was found between the number of nests and the monthly rainfall during both years $(\mathrm{r}=0.39$; d.f. $=11 ; \mathrm{p}=$ 0.206 , for 1999 and $\mathrm{r}=0.33$; d.f. $=11 ; \mathrm{p}=0.298$, for 2000), while in Ipirá the correlation was highly significant $(\mathrm{r}=0.72$; d.f. $=11$; $p=0.008$ ) for the period from January to December 2000 .

\section{Bionomical aspects of the species}

Centris tarsata occurred in both areas (Tabs I, II and III). Females of this species used all types of trap establishing $72 \%$ of the nests in large tubes, 25\% in bamboo canes and 3\% in small tubes. The bamboo canes utilized by the bees ranged from 8 to $13 \mathrm{~mm}$ in diameter, but most nests (87\%) were established in 
canes either $9 \mathrm{~mm}$ or $10 \mathrm{~mm}$. The bees constructed their nests with a mixture of sand and oil. Completed nests had two to three cells in small tubes, one to seven cells in large tubes, and two to 13 cells in bamboo canes. The analyses of the contents of 266 cells (133 from each area) showed a similar total mortality between Baixa Grande (52.6 \% of the cells) and Ipirá (58.6\%) $\left(\chi^{2}=0.97 ;\right.$ d.f. $\left.=1 ; \mathrm{p}=0.323\right)$. M. bicolor and two species of Coelioxys were the insect parasites associated with the nests. The parasitism rates were $11 \%$ and $16 \%$ in Baixa Grande and Ipirá, respectively. In Baixa Grande, M. bicolor was the main enemy, accounting for $73.3 \%$ of all cells parasitized, while in Ipirá, other parasitic bees were the most destructive enemies, accounting for $63.6 \%$ of all cells parasitized. In Baixa Grande, the sex ratio (4.5 males: 1 female) was significantly males biased $\left(\chi^{2}=36.5\right.$; d.f. $=1 ; \mathrm{p}=0.00)$, while in Ipirá, it was not significantly different from 1:1 (1.1 males: 1 female; $\chi^{2}=0.15$; d.f. $\left.=1 ; \mathrm{p}=0.691\right)$

Centris analis Fabricius, 1804 nested in Baixa Grande only (Tabs I and II). Of the nine nests obtained, five were established in large tubes, three in small tubes, and one in bamboo cane. The cells were constructed with a material similar to fine wood chips. Completed nests had three cells in small tubes $(n=3)$ and four $(n=3)$ or five $(n=2)$ brood cells in large tubes, arranged linearly beginning at the back of the trap. The nest established in a bamboo cane had one cell only. The measurements of the cells ranged from 10 to $14.9 \mathrm{~mm}$ in length $(\mathrm{x}=12.7 \pm 1.8 \mathrm{~mm} ; \mathrm{n}$ $=7)$ and from 6.8 to $7.6 \mathrm{~mm}$ in maximum width $(\mathrm{x}=7.3 \pm 0.3$ $\mathrm{mm} ; \mathrm{n}=8)$. The nests constructed in small tubes and two of them constructed in large tubes had an empty vestibular cell at the entrance. In these nests the plug had been built at the entrance of the trap. From two nests six individuals emerged before the nests being removed to the laboratory. Of the remaining nests emerged five males and seven females, and seven cells contained dead immatures. These immatures died in the egg stage ( 1 cell), larval stage ( 1 cell), and pre-emergent adults (5 cells).

Xylocopa frontalis (Olivier, 1789) occurred in both areas (Tabs I, II and III) and nested in bamboo canes only. The traps utilized by bees had diameter higher than $18 \mathrm{~mm}$, and $75 \%$ of the nests occupied traps ranging from 20 to $22 \mathrm{~mm}$ in diameter. The females scraped the inner walls of the bamboo cane with their mandibles producing sawdust, used to make the cell partitions.

Nests of Tetrapedia diversipes Klug, 1810 were obtained from Baixa Grande only (Tabs I and II). Of the 27 nests obtained, eigth had been established in small tubes and 19 in large tubes. The bees constructed their nests with a mixture of sand and oil, and the number of cells per nest ranged from two to nine. The interval between collection date of the nests and adult emergence was about 8 weeks, but in two nests there were larva and pupa 8 months after they have been removed from the field. Of the 92 cells analysed, 43 cells produced males and females, one cell produced a male $C$. waltheriae, and 48 cells contained dead immatures that had died of unknown causes. The immatures died in the egg stage ( 6 cells), larval stage ( 3 cells), pupal stage (9 cells), and as pre-emergent adults (30 cells). Of these 30 preemergent adults found dead in the cells, 22 of them were identified as male or female. These individuals together with those emerged from the 43 cells resulted in a total sex ratio not significantly different from $1: 1\left(\chi^{2}=0.13 ; \mathrm{df}=1 ; \mathrm{p}=0.709\right)$.

Euglossa cordata (Linnaeus, 1758) occurred in both areas (Tab. I) but nested with higher frequency in Ipirá (27 nests) (Tab. III) than Baixa Grande (10 nests) (Tab. II). The bamboo canes utilized by bees ranged from 12 to $26.5 \mathrm{~cm}$ in length and from 1 to $2 \mathrm{~cm}$ in diameter. All of the nests had a resinous wall recessed from the trap entrance in which was a small circular hole just large enough for the female to pass. The distance from resinous wall to bamboo cane entrance ranged from 2 to 9.3 $\mathrm{cm}$. In most cases, however, that distance was smaller than 5 $\mathrm{cm}$. The nests did not show any inner wall coating; some of them had resinous particles deposited near the nest entrance. The number of cell per nest ranged from 1 to 12 , but $88.6 \%$ of the nests contained 1-6 cells only. The cells were made of dark or pale brown resin and $11.2-15 \mathrm{~mm}$ long $(\mathrm{x}=12.6 \pm 0.8 \mathrm{~mm}$; $\mathrm{n}=16)$ by $7.2-10 \mathrm{~mm}$ in maximum diameter $(\mathrm{x}=7.9 \pm 0.6$ $\mathrm{mm} ; \mathrm{n}=16$ ). The cells were constructed in rows (two parallel rows in the nest with 12 cells) with the long axes tending to be vertical or inclined. They could be found in isolated series with the cells of each series built in close contact or some cells could be isolated and other cells could be together. In general, adults emerged 7 to 8 weeks after nests were removed from the field, and 59 days was the maximum interval between collection date of the nest and adult emergence. In Baixa Grande, adult bees emerged from 22 of 28 constructed cells in the nests; the six remaining cells contained dead pre-emergent adults. The sex ratio of 28 individuals produced in the nests, emerged $(n=22)$ and dead in the cells $(n=6)$, was $53.6 \%$ females to $46.4 \%$ males, which is not significantly different from a $1: 1$ sex ratio $\left(\chi^{2}=\right.$ $0.14 ; \mathrm{df}=1 ; \mathrm{p}=0.705)$. In addition to the 14 males and 8 females that were produced from the nests collected in Ipirá, 7 males and 15 females were found dead in the cells. Considering the live and dead individuals together, the sex ratio was 52.3 females to 47.7 males, which is not significantly different from a $1: 1$ sex ratio $\left(\chi^{2}=0.09 ; \mathrm{df}=1 ; \mathrm{p}=0.763\right)$.

Dicranthidium luciae Urban, 1992 and Dicranthidium arenarium (Ducke, 1907) were recorded in Baixa Grande only (Tabs I and II). D. luciae nested in small tubes. Three females and six males emerged from the two nests. D. arenarium established its nests in small tubes $(n=13)$ and bamboo cane $(n=$ 1). The cells of both species were constructed with a hardened resinous material, pale brown in colour, and arranged in a linear series, forming a continous cylindrical structure. In most nests there was a single row of cells, but two parallel rows were found in some nests. For both species, emergence of adults occurred 28-32 days after nests were removed from the field. Of the 46 brood cells built in the 14 nests of $D$. arenarium, only 25 (54.3\%) produced adult bees: 15 males and 10 females. The 
remaining cells $(n=21)$ contained dead immatures from unknown causes. The immatures died in the egg stage (4 cells), larval stage (9 cells), and pre-emergent adults ( 8 cells). The individuals emerged together with the males and females found dead in the cells, resulted in a total sex ratio not significantly different from 1:1 $\left(\chi^{2}=1.48 ; \mathrm{df}=1 ; \mathrm{p}=0.223\right)$.

Megachile lissotate Moure, 1943 occurred in Ipirá only (Tabs I and III). The nests were established in bamboo canes $10.2-19.1 \mathrm{~cm}$ long and $0.7-1.1 \mathrm{~cm}$ in diameter. The first cell was always constructed in the end of the trap. Subsequent cells were constructed with their bases adjoining the closing of earlier cells so the cells formed a continuous linear series. The inner end of the cell and the cell walls were made with overlapping leaf pieces. The number of brood cells per nest ranged from two to five and they were $8-12.5 \mathrm{~mm}$ long $(\mathrm{x}=10.4 \pm 1.3$ $\mathrm{mm} ; \mathrm{n}=17)$ by $5.7-6.8 \mathrm{~mm}$ in outer diameter $(\mathrm{x}=6.2 \pm 0.4$ $\mathrm{mm} ; \mathrm{n}=17)$. The cells were closed by up to six circular leaf pieces. The nest plugs were usually made with $12-14$ circular leaf pieces, and they were built recessed from the trap entrance. The distance from nest plug to trap entrance was usually longer than $8 \mathrm{~cm}$.

\section{DISCUSSION}

\section{Species richness and abundance}

In the studies carried out in Brazil with trap-nests, the species richness of bees nesting in such cavities has been highly variable. This variation, however, must be interpreted cautiously because, in addition to the potential diversity of species in the study area (Alves-DOS-SANTOS 2003), the results can be affected by different man-made nesting materials (Bosch 1995), trapnest diameter (VANDENBERG 1995), height of trap-nests in relation to ground level (Morato 2001), exposure of trap-nests to sun (FrANKIE et al. 1988), availabity of natural preexisting cavities (Viana et al. 2001), and by the period of sampling. Irrespective of these variables, some general patterns has emerged from the studies made. As observed in the present study, the community structure shows most species with few nests and few species with many nests, and forested habitats have shown higher species richness than habitats with open vegetation (Camillo et al. 1995, Garófalo 2000, Morato \& Campos 2000, VIANA et al. 2001). Although the period of sampling in Baixa Grande was larger than in Ipirá, the species richness found for the period in which both areas were simultaneously sampled was highest in Baixa Grande. Therefore, the differences between habitats may be associated with corresponding differences in plant species number in each of them since habitats with high floral diversity offer better and richer food resources for the bees, thereby supporting more bee species (Heithaus 1979, GATHMANn et al. 1994, TschaRnTKE et al. 1998).

The highest trap-nesting bee species richness has been found in studies made in mesophilic semi-deciduous forests in the state of São Paulo. From two sampling sites in Cajuru, CAMILLO et al. (1995) reported the occurrence of 25 and 21 species nest- ing in those habitats, and in Serra do Japi (Jundiai), 17 species nested in the traps (GARófalo 2000). These figures as also that found by Morato \& Campos (2000) in Amazonic forest (Central Amazonia, 14 species), are higher than that obtained in this work in a dry semideciduous forest (Baixa Grande, 11 species). On the other hand, the species richness in the caatinga in Ipirá (7 species) was similar to that found for sand dunes areas in Salvador, Bahia (7 species) by VIANA et al. (2001), and higher than those reported by AGUiar \& Martins (2002) for habitats of open savanna (5 to 8 species) and closed forest at Guaribas Biological Reserve (2 species, in Mamanguape, Paraíba). The low species richness of bees found in the caatinga and in the sand dunes coincides with the patterns observed from collecting of bees at flowers (Martins 1994, Aguiar \& Martins 1997, Viana 1999, Viana \& Alvesdos-Santos 2002, Aguiar \& Zanella 2005). According to some authors (GARÓFALO 2000, Viana et al. 2001) the species richness found in their studies may be underestimated because not all species present in the habitats were attracted to nest in the traps. Considering that $C$. analis, $T$. diversipes, $D$. arenarium and $D$. luciae are species that occurr in the caatinga (ZANELla 2000), the absence of them in the samples from Ipira indicates that the species richness found in this work can be also underestimated. Thus, as pointed out by GARÓFALO (2000), multiple sampling stations within habitat are necessary to a better knowledge on the number of species present in that habitat.

The studies made in Brazil have shown that Centris species are usually those that nest at highest frequency in trapnests (Camillo et al. 1995, Morato \& Campos 2000, Viana et al. 2001, Aguiar \& Martins 2002). In northeastern region has been observed a predominance of nesting by $C$. tarsata in semi-deciduous forest (37\% of the total of nests in this work), in the Atlantic forest (58\%) and coastal savanna (39\% - 52\%) (Aguiar $\&$ Martins 2002) as well as in sand dunes (58\%) (VIANA et al. 2001) and caatinga (55\% in this work) areas. These data reveal, thus, that C. tarsata is successful in nesting in hot and open vegetation, in forest areas and in agricultural (as site BG-II) and human disturbed areas (as site IP-III) since there are available cavities. On the other hand, $C$. analis nested only in coastal savanna and in closed forest (Aguiar \& MARTins 2002) and, as observed in this study, in forested areas. Although this species showed low nesting frequency in Baixa Grande, it was the second most abundant species at Guariba Biological Reserva (Aguiar \& Martins 2002). It is important to observe that while C. tarsata is a predominant species in some areas of the northeastern part of Brazil (Viana et al. 2001, Aguiar 2002, Aguiar \& Martins 2002, Aguiar \& Garófalo 2004), C. analis is, usually, the most abundant Centris species in forest fragments of the southeastern part (CAMillo et al. 1995, Garófalo 2000).

Of the sampled species in the caatinga (this work), in sand dunes (VIANA et al. 2001) and in coastal savannas (AgUiar \& MarTins 2002), only E. cordata e C. tarsata occurred in the three habitats. These environments share some similarities as the open vegetation, high temperatures and insolation and can 
be characterized by showing low species richness ( 7 or 8 species nesting in traps) and a high nesting frequency by $C$. tarsata. Although the total number of nests in the caatinga was twice higher than that found in the sand dunes, the number of nests per species was similar, each area showing most nests distributed by two species while the remaining species nested few times (usually less than six nests each).

\section{Nesting season}

Fluctuations in annual frequencies of nesting, as occurred in this study, have also been reported by other authors (FrankIE et al. 1993, 1998, Morato et al. 1999, Pereira et al. 1999, Viana et al. 2001, Aguiar \& Garófalo 2004) working with trap-nests. FrANKIE et al. (1998) suggested that such fluctuations would be a regular characteristic of cavity-nesting bee species, and that different species would be affected differently by climatic changes between years. According to FrankIE et al. (1998), the yearly variations in nesting frequency could be driven by factors such as differential natural mortality, extreme annual climatic patterns (drought or above normal rainfall), or the disturbance of marginal habitats.

Although there was a tendency of the nesting activties occur in highest frequencies during the wet season in both areas, only in Ipirá the association between the two variables, frequency of nesting and monthly rainfall, was strongly positive. The absence of a similar association in Baixa Grande indicates, as observed in this study, that the duration of the favorable nesting period in this area is larger than that of Ipirá. C. tarsata, E. cordata, and $X$. frontalis showed long reproductive seasons, producing more than one generation per year. Other species were more seasonal, such as $T$. diversipes and $D$. arenarium. The great variation (from 8 weeks up to 8 months) in the egg-to-adult period of $T$. diversipes indicates that some of the progeny produced at the end of the reproduction season (March, April) enter diapause. Similar observations were reported by Alves-DosSantos et al. (2002), for T. diversipes, and Camillo (2000), for Tetrapedia curvitarsis Friese 1899, nesting in the state of São Paulo. Some of the progeny of $C$. tarsata also undergo diapause in at least one of the generations during the year (Aguiar \& GARófalo 2004). The occurrence of diapause in mature larva and pupa can be viewed as a survival strategy during unfavourable environment periods, and can reduce the risk of local population extinctions (MARTINs et al. 2001). The temperature was high throughout the year (above $20^{\circ} \mathrm{C}$ ) at both study sites, and probably did not directly affect the reproductive activities of solitary bees. It is possible that a low abundance of floral resources in the dry season (autum/winter) restrains reproduction, but more research is needed on the temporal fluctuations of this resource in order to fully test this hypothesis.

\section{Some aspects of the nests}

Nests of most of the species recorded in this study have been previously described by other authors who also studied aspects of the nesting biology of these bees, as for example
Camillo \& Garófalo (1982) (Xylocopa grisescens Lepeletier, 1841 and $X$. frontalis), Garófalo (1992) (E. cordata), Jesus \& Garófalo (2000) (C. analis), Silva et al. (2001), Aguiar \& Garófalo (2004) (C. tarsata), and Alves-Dos-SAntos et al. 2002 (T. diversipes).

Considerable intraspecific variation in the number of cells per nest in different species was observed in this study. This variation may be related to the space available for cell construction (Michener \& LANGe 1958), to the diameter of the trapnest (VANDEnberg 1995, Parker 1986), changes in quality or abundance of floral resources along the nesting season, and/or to the decline of the foraging capacity of older females (Torchio \& TEPEDINo 1980). Variation in the fecundity of solitary bees also depends on the availability of floral resources and the duration of the nesting season (Bosch 1994a, b, c).

Studies of tropical bees have shown that $C$. analis constructs from 1 to 3 nests, producing up to 9 cells per female (Jesus \& Garófalo 2000), while Centris vittata Lepeletier 1841 produces a maximum of 11 cells per female (Pereira et al. 1999). In the present study, the maximum number of cells recorded in a nest of $C$. tarsata was 13 , considerably greater than previous reports for this species (8 cells) (Silva et al. 2001). At another site (Monte Santo, Bahia), a nest of C. tarsata had 15 cells which produced 11 males and 4 females (AgUIAR, personal observation). However, it will be necessary to mark the females and follow them through the nesting season in order to make more definitive evaluations of their reproductive capacity. The maximum number of cells observed for E. cordata nests was lower than the maximum recorded by BENNETT (1966) (13 cells), but greater than that reported by GARÓFALO (1992) (10 cells). Most nests had cell numbers within the variation reported by GARÓFALO (1992).

Several species only nested in bamboo canes, while $T$. diversipes preferred cardboard tubes. This suggests that the used material to build the trap-nests may also influence the choice of nesting cavities. Some species have shown variations in their acceptance of different kinds of trap-nests in different studies. In the present study, E. cordata established no nests in cardboard tubes, although this species has reportedly used cardboard trap-nest in sites where bamboo canes were not available (such as in Mamanguape, Paraíba) (Aguiar \& Martins 2002). GARÓFALO et al. (1993) noted a preference of Euglossa Latreille, 1802 females for bamboo canes. This species will also nest in other cavities, such as old nests of Xylocopa Latreille, 1802 dead tree trunks, and wooden boxes (GARÓFALO 1992). Xylocopa females need sawdust to construct cellular partitions and this restricts the use of traps that do not provide this material. The nests of these species have been reported in tree trunks (CAMILLO \& Garófalo 1982) and in pieces of sawn wood (VIANA et al. 2001, Oliveira-Filho \& Freitas 2003). Besides allowing the observation of intra-nest behaviour, trap-nests made of bamboo canes can be a cheap alternative for rearing and managing Xylocopa populations used in crop pollination.

The utilization of different kinds of materials as trap-nests as well as a variety of cavity dimensions mainly of bamboo 
canes, allowed nesting by bee species of many sizes, and with different preferences for nesting cavities. So the sampling technique efficiency is improved with the use of several kinds of trap-nests.

Some of the native pollinators observed in this study, mainly $C$. tarsata and $X$. frontalis, show a potential for management as crop pollinators (Freitas 1997, Freitas et al. 1999, Freitas \& Oliveira-Filho 2003), increasing the importance of further studies to elucidate details of their nesting biology and resource requirements, as well as techniques for their management and breeding.

\section{ACKNOWLEDGMENTS}

We are grateful to Adélia Oliveira and Alberto Bispo, owners of the farms, for allowing us free access to their land, and to Dr. Fernando C. V. Zanella and to Dr. Márcio Oliveira, for identifying bees species. C.M.L. Aguiar received a grant from the Conselho Nacional de Desenvolvimento Científico e Tecnológico (CNPq).

\section{REFERENCES}

Aguiar, C.M.L. 2002. Abelhas (Hymenoptera, Apoidea) que nidificam em ninhos-armadilha, em áreas de caatinga e floresta estacional semi-decídua do estado da Bahia, Brasil. Anais do Encontro sobre Abelhas, Ribeirão Preto, 5: 53-57.

Aguiar, C.M.L \& C.A. Garófalo. 2004. Nesting biology of Centris (Hemisiella) tarsata (Hymenoptera, Apidae, Centridini). Revista Brasileira de Zoologia, Curitiba, 21 (3): 477-486.

Aguiar, C.M.L \& C.F. Martins. 1997. Abundância relativa, diversidade e fenologia de abelhas (Hymenoptera, Apoidea) na caatinga, São João do Cariri, Paraíba, Brasil. Iheringia, Série Zoologia, Porto Alegre, 83: 151-163.

Aguiar, C.M.L \& F.C.V. Zanella 2005. Estrutura da Comunidade de Abelhas (Hymenoptera: Apoidea: Apiformis) de uma Área na Margem do Domínio da Caatinga (Itatim, BA). Neotropical Entomology, Londrina, 34 (1): 15-24.

Aguiar, A.J.C. \& C.F. Martins. 2002. Abelhas e vespas solitárias em ninhos-armadilha na Reserva Biológica Guaribas (Mamanguape, Paraíba, Brasil). Revista Brasileira de Zoologia, Curitiba, 19 (Supl. 1): 101-116.

Alves-dos-Santos, I. 2003. Trap-nesting bees and wasps on the University Campus in São Paulo, Southeastern Brazil (Hymenoptera: Aculeata). Journal of the Kansas Entomological Society, Lawrence, 76: 328-334.

Alves-dos-Santos, I.; G.A.R. Melo \& J.G. Rozen. 2002. Biology and immature stages of the bee tribe Tetrapediini (Hymnoptera: Apidae). American Museum Novitates, New York, 3377: 1-45.

BАHIA. 1994. Informações básicas sobre os municípios baianos. Região Paraguaçu. Salvador, Centro de Estatísticas e Informações, vol. 14, p. 98-100, p. 360-362.

BenNetT, F.D. 1966. Notes on the biology of Stelis (Odontostelis) bilineolata (Spinola), a parasite of Euglossa cordata (Linnaeus) (Hymenoptera: Apoidea: Megachilidae). Journal of the New York Entomological Society, Washington, 74:72-79.

Bosch, J. 1994a. Osmia cornuta (Latr) (Hymenoptera, Megachilidae) as a potential pollinator in almond orchards: releasing methods and nest-hole length. Journal of Applied Entomology, Berlin, 117: 151-157.

Bosch, J. 1994b. The nesting behavior of the mason bee Osmia cornuta (Latr) with special reference to its pollinating potential (Hymenoptera, Megachilidae). Apidologie, Les Ulis, 25: 84-93.

Bosch, J. 1994c. Improvement of field management of Osmia cornuta (Latr) for almond pollination (Hymenoptera, Megachilidae). Apidologie, Les Ulis, 25 (1): 62-74.

Bosch, J. 1995. Comparison of nesting materials for the orchard pollinator Osmia cornuta (Hymenoptera: Megachilidae). Entomologia Generalis, Stuttgart, 19: 285-289.

Camillo, E. 2000. Biologia de Tetrapedia curvitarsis em ninhosarmadilha (Hymenoptera: Apidae: Tetrapediini). Anais do Encontro sobre Abelhas, Ribeirão Preto, 5: 53-57.

Camillo, E. \& C.A. Garófalo. 1982. On the bionomics of Xylocopa frontalis (Olivier) and Xylocopa grisescens (Lepeletier) in southern Brazil. I. Nest construction and biological cycle. Revista Brasileira de Biologia, Rio de Janeiro, 42: 571-582.

Camillo, E.; C.A. Garófalo; J.C. Serrano \& G. Muccillo. 1995. Diversidade e abundância sazonal de abelhas e vespas solitárias em ninhos armadilhas (Hymenoptera, Apocrita, Aculeata). Revista Brasileira de Entomologia, São Paulo, 39 (2): 459-470.

Frankie, G.W.; S.B. Vinson; L. Newstrom \& J.F. Barthell. 1988. Nest site and habitat preferences of Centris bees in the Costa Rican dry forest. Biotropica, Lawrence, 20 (4): 301-310.

Frankie, G.W.; L. Newstrom; S.B. Vinson \& J.F. Barthell. 1993. Nesting habitat preferences of selected Centris bee species in Costa Rica dry forest. Biotropica, Lawrence, 25 (3): 322-333.

Frankie, G.W.; S.B. Vinson; M.A. Rizzardi; T.L.Griswold; S. O’Keefe \& R.R. SNELLING. 1998. Diversity and abundance of bees visiting a mass flowering tree species in disturbed seasonal dry forest, Costa Rica. Journal of the Kansas Entomological Society, Lawrence, 70 (4): 281-296.

Freitas, B.M. 1997. Number and distribution of cashew (Anacardium occidentale) pollen grains on the bodies of its pollinators, Apis mellifera and Centris tarsata. Journal of Apicultural Research, Cardiff, 36: 15-22.

Freitas, B.M.; J.E. Alves; G.F. Brandão \& Z.B. Araújo. 1999. Pollination Requirements of West Indian Cherry (Malpighia emarginata) and its Putative Pollinators, Centris Bees, in NE Brazil. Journal of Agricultural Science, Cambridge, 133: 303-311.

Freitas, B.M. \& J.H. Oliveira-Filho. 2003. Ninhos racionais para mamangavas (Xylocopa frontalis) na polinização do maracujá-amarelo (Passiflora edulis). Ciência Rural, Santa Maria, 33 (6): 1135-1139. 
Garófalo, C.A. 1992. Comportamento de nidificação e estrutura de ninhos de Euglossa cordata ((Hymenoptera: Apidae: Euglossini). Revista Brasileira de Biologia, Rio de Janeiro, 52 (1): 187-198.

Garófalo, C.A. 2000. Comunidade de abelhas (Hymenoptera, Apoidea) que utilizam ninhos-armadilha em fragmentos de matas do Estado de São Paulo. Anais do Encontro sobre Abelhas, Ribeirão Preto, 4: 121-128.

Garófalo, C.A.; E. Camillo; J.C. Serrano \& J.M.M. Rebêlo. 1993. Utilization of trap nests by Euglossini species (Hymenoptera: Apidae). Revista Brasileira de Biologia, Rio de Janeiro, 53 (2): 177-187.

Gathmann, A.; H-J. Greiler \& T. TscharntKe. 1994. Trap-nesting bees and wasps colonizing set-aside fields: sucession and body size, management by cutting and sowing. Oecologia, Heidelberg, 98: 8-14.

Gazola, A.L. \& C.A. Garófalo. 2003. Parasitic behavior of Leucospis cayennensis Westwood (Hymenoptera: Leucospidae) and rates of parasitism in populations of Centris (Heterocentris) analis (Fabricius) (Hymenoptera: Apidae: Centridini). Journal of the Kansas Entomological Society, Lawrence, 76 (2): 131-142.

Heithaus, E.R. 1979. Community structure of neotropical flower visiting bees and wasps: diversity and phenology. Ecology,Washington, 60: 190-202.

JAYASINGH, D.B. \& B.E. FreEMAN. 1980. The comparative population dynamics of eight solitary bees and wasps (Aculeata; Apocrita; Hymenoptera) trap-nested in Jamaica. Biotropica, Lawrence, 12: 214-219.

Jesus, B.M.V. \& C.A. GaróFALo. 2000. Nesting behaviour of Centris (Heterocentris) analis (Fabricius) in southeastern Brazil (Hymenoptera, Apidae, Centridini). Apidologie, Les Ulis, 31: 503-515

Krombein, K.V. 1967. Trap-nesting wasps and bees. Life histories, nests and associates. Washington, Smithsonian Press, 570p.

Kruess, A. \& T. TscharntKe. 2002. Grazing intensity and the diversity of grasshoppers, butterflies, and trap-nesting bees and wasps. Consevation Biology, Malden, 16: 1570-1580.

Martins, C.F. 1994. Comunidade de abelhas (Hym., Apoidea) da caatinga e do cerrado com elementos de campos rupestres do estado da Bahia, Brasil. Revista Nordestina de Biologia, João Pessoa, 9 (2): 225-257.

Martins, R.P.; S.T.M. Guerra \& M.S. Barbeitos. 2001. Variability in egg-to-adult development time in the bee Ptilothrix plumata and its parasitoids. Ecological Entomology, Oxford, 26: 609-616.

Michener, C.D \& R.B. Lange. 1958. Observations on the ethology of Neotropical Anthophorine bees (Hymenoptera: Apoidea). University of Kansas Science Bulletin, Lawrence, 39 (3): 69-96

Morato, E.F. 2001. Efeitos da fragmentação florestal sobre vespas e abelhas solitárias na Amazônia Central. II. Estratifi- cação vertical. Revista Brasileira de Zoologia, Curitiba, 18 (3): 737-748.

Morato, E.F. \& L.A.O. Campos. 2000. Efeitos da fragmentação florestal sobre vespas e abelhas solitárias em uma área da Amazônia Central. Revista Brasileira de Zoologia, Curitiba, 17 (2): 429-444.

Morato, E.F; M.V.B. Garcia \& L.A.O. Campos. 1999. Biologia de Centris Fabricius (Hymenoptera, Anthophoridae, Centridini) em matas contínuas e fragmentos na Amazônia Central. Revista Brasileira de Zoologia, Curitiba, 16 (4): 1213-1222.

Oliveira-Filho, J.H. \& Freitas, B.M. 2003. Colonização e biologia reprodutiva de Xylocopa frontalis em um modelo de ninho racional. Ciência e Cultura, São Paulo, 33 (4): 693-697.

PArker, F.D. 1986. Nesting, associates, and mortality of Osmia sanrafaelae Parker. Journal of the Kansas Entomological Society, Lawrence, 59: 367-377.

Pereira, M.; C.A. Garófalo; E. Camillo \& J.C. Serrano. 1999. Nesting biology of Centris (Hemisiella) vittata Lepeletier in southeastern Brazil (Hymenoptera, Apidae, Centridini). Apidologie, Les Ulis, 30: 327-338

ScotT, V.L.; S.T. KelLey \& K. STRICKLer. 2000. Reproductive biology of two Coelioxys cleptoparasites in relation to their Megachile hosts (Hymenoptera: Megachilidae). Annals of the Entomological Society of America, Washington, 93: 941948.

Silva, F.O.; B.F. Viana \& E.L. Neves. 2001. Biologia e arquitetura de ninhos de Centris (Hemisiella) tarsata Smith (Hymenoptera: Apidae: Centridini). Neotropical Entomology, Londrina, 30: 541-545.

STEFfan-Dewenter, I. 2002. Landscape context affects trap-nesting bees, wasps, and their natural enemies. Ecological Entomology, Oxford, 27: 631-637.

Strickler, K.; V.L. SCOTt \& R.L. Fischer. 1996. Comparative nesting ecology of two sympatric leafcutting bees that differ in body size (Hymenoptera: Megachilidae). Journal of the Kansas Entomological Society, Lawrence, 69: 26-44.

Torchio, P.F. \& V.J. Tepedino. 1980. Sex ratio, body size and seasonality in solitary bee, Osmia lignaria propinqua Cresson (Hymenoptera: Megachilidae). Evolution, Lawrence, 34: 993-1003.

Tscharntke, T; A. Gathmann \& I. Steffan-Dewenter. 1998. Bioindication using trap-nesting bees and wasps and their natural enemies: community structure and interactions. Journal of Applied Ecology, London, 35: 708-719.

VAndenberg, J.D. 1995. Nesting preferences of the solitary bee Osmia sanrafaelae (Hymenoptera: Megachilidae). Journal of Economic Entomology, Lanham, 88: 592-599.

VIANA, B.F. 1999. A comunidade de abelhas (Hymenoptera: Apoidea) das dunas interiores do Rio São Francisco, Bahia, Brasil. Anais da Sociedade Entomológica do Brasil, Londrina, 28: 635-645.

VIANA, B.F. \& I. Alves-DOS-SANTOS. 2002. Bee diversity of the coastal sand dunes of Brazil, p. 135-153. In: P.G. KeVAN \& V.L. IMPE- 
RATRIZ-FonseCA (Eds). Pollinating bees: the conservation link between agriculture and nature. Brasília, Ministério do Meio Ambiente, 313p.

Viana, B.F.; F.O. Silva \& A.M.P. Kleinert. 2001. Diversidade e sazonalidade de abelhas solitárias (Hymenoptera: Apoidea) em dunas litorâneas no Nordeste do Brasil. Neotropical Entomology, Londrina, 30: 245-251.

Zanella, F.C.V. 2000. The bees of the Caatinga (Hymenoptera, Apoidea, Apiformes): a species list and comparative notes regarding their distribution. Apidologie, Les Ulis, 31: 579592.

Zar, J.H. 1984. Biostatistical Analysis. New Jersey, PrenticeHall, 718p.

Zillikens, A. \& J. STEINER. 2004. Nest architecture, life cycle and cleptoparasite of the neotropical leaf-cutting bee Megachile (Chrysosarus) pseudanthidioides Moure (Hymenoptera: Megachilidae). Journal of the Kansas Entomological Society, Lawrence, 77: 193-202.

Received in 06.IV.2005; accepted in 07.XI.2005. 